\title{
Behavioral factors associated with HCV and HIV co-infection in residents of São Paulo, Brazil
}

\author{
Norma Farias", Umbeliana Barbosa de Oliveira, lára de Souza, Débora Moraes Coelho, Claudia Afonso Binelli \\ From 17th International Symposium on HIV and Emerging Infectious Diseases (ISHEID) \\ Marseille, France. 23-25 May 2012
}

\section{Introduction}

To date, there are no surveys in Brazil on the occurrence of co-infection hepatitis and HIV in the general population. The aim of the present study was to investigate factors associated with HIV/HCV co-infection among residents in the State of Sao Paulo, Brazil, notified at the National Databank of Major Causes of Morbidity.

\section{Material and methods}

We reviewed 3,032 cases of HIV/HCV co-infection among 46,969 bank records of viral hepatitis from January 2007 to March 2010. The hepatitis C cases were confirmed by the presence of HCV RNA using reverse transcription-polymerase chain reaction (RT-PCR) in anti-HCV-positive samples. The diagnosis of HIV/AIDS and data on demographic and behavioral aspects were collected through epidemiologic investigation forms. Variables associated with HCV/HIV co-infection were identified with Poisson regression model and confidence intervals of $95 \%$.

\section{Results}

The majority were male (73\%), white (65\%) and had less than 50 years $(65 \%)$. In a adjusted analysis, the prevalence ratio was 1.27 (CI 95\%:1.04-1.55) for sexual contact with patients with HVB or HCV, 1.48(CI 95\%: 1.271,73) for 3 or more sexual partners, 1.73 (CI 95\%: 1.382.16) for STD, 2.95 (95\% CI:2.42-3.59) among IDU and $1.78(95 \%$ CI:1.49-2.17) among inhalable drug users or crack.

\section{Conclusions}

These data show that illicit drug use is the main factor associated with co-infection HCV / HIV in São Paulo.

* Correspondence: norma.o.farias@gmail.com

State Secretary of Health of São Paulo, São Paulo, Brazil
Sexual transmission suggested to play a role in coinfected HCV / HIV.

Published: 25 May 2012

doi:10.1186/1742-4690-9-S1-P130

Cite this article as: Farias et al:: Behavioral factors associated with HCV and HIV co-infection in residents of São Paulo, Brazil. Retrovirology 2012 9(Suppl 1):P130.
Submit your next manuscript to BioMed Central and take full advantage of:

- Convenient online submission

- Thorough peer review

- No space constraints or color figure charges

- Immediate publication on acceptance

- Inclusion in PubMed, CAS, Scopus and Google Scholar

- Research which is freely available for redistribution
C Biomed Central 